\title{
Increase in Secretory Sphingomyelinase Activity and Specific Ceramides in the Aorta of Apolipoprotein E Knockout Mice during Aging
}

\author{
Keiko Kobayashi, ${ }^{*, a}$ Eri Nagata, ${ }^{a}$ Kazuki Sasaki, ${ }^{a}$ Mariko Harada-Shiba, ${ }^{b}$ Shosuke Kojo, ${ }^{* c}$ and \\ Hiroe Kikuzaki $^{a}$ \\ ${ }^{a}$ Department of Food Science and Nutrition, Nara Women's University; Nara 630-8506, Japan: ${ }^{b}$ Department of \\ Molecular Innovation in Lipidology, National Cerebral and Cardiovascular Center Research Institute; Suita, Osaka \\ 565-8565, Japan: and ${ }^{c}$ The Open University of Japan; Wakaba, Mihama, Chiba 261-8586, Japan.
}

Received March 2, 2013; accepted May 12, 2013

\begin{abstract}
Atherosclerosis is caused by many factors, one of which is oxidative stress. We recently demonstrated that systemic oxidative stress increased secretory sphingomyelinase (sSMase) activity and generated ceramides in the plasma of diabetic rats. In addition, we also showed that the total ceramide level in human plasma correlated with the level of oxidized low-density lipoprotein. To investigate the relationship between ceramide species and atherogenesis during aging, we compared age-related changes in ceramide metabolism in apolipoprotein $\mathbf{E}$ knock out mice $\left(\mathrm{apoE}^{-/-}\right.$) and wild type mice (WT). Although the total plasma ceramide level was higher in $\operatorname{apoE}^{-/-}$than that in WT at all ages, it decreased with increasing age. sSMase activity increased at 65 weeks (w) of age in both strains of mice. When apo $E^{-/-}$developed atherosclerosis at $15 \mathrm{w}$ of age, C18:0, C22:0, and C24:0 ceramide levels in the $\operatorname{apoE}^{-/-}$aorta significantly increased. Furthermore, at 65 w of age C16:0 and C24:1 ceramide levels were significantly higher than those in WT. These results suggested that elevation in levels of specific ceramide species due to sSMase activity contributed to atherogenesis during aging.
\end{abstract}

Key words aging; apolipoprotein E; atherosclerosis; ceramide; sphingomyelinase

Cardiovascular disease is associated with aging. Hyperlipidemia and long-term exposure to various stimuli such as oxidative stress lead to atherosclerosis. Despite several indications that aging causes atherosclerosis, a specific factor associated with atherosclerosis that increases or decreases with aging is yet to be entirely identified. One possible factor is elevation of bioactive lipid such as ceramide. Ceramide regulates cell cycle arrest, apoptosis, and cellular senescence, ${ }^{1)}$ and serves as an intracellular second messenger in these processes. ${ }^{2)}$ Oxidative stress inducers such as UV light, antineoplastic drugs, and radiation stimulate ceramide accumulation in the cell. ${ }^{3-6)}$ Ceramide belongs to the sphingolipid family and comprises a saturated or unsaturated fatty acid of $\mathrm{C} 16-\mathrm{C} 26$ chain length bound to the amino group of sphingosine.

Ceramide is generated by de novo synthetic pathway as well as from the hydrolysis of sphingomyelin (SM) by sphingomyelinase (SMase). Sphingomyelinases are classified into five types on the basis of their optimum $\mathrm{pH}$, subcellular localization, and cation dependence. ${ }^{5,7}$ Among these enzymes acid SMase (aSMase) (optimal $\mathrm{pH}=4.8$ ) operates in the endosomal/ lysosomal compartment or plasma membrane. ${ }^{8)}$ Of note, the aSMase gene (smpdl) gives rise to two different enzymes lysosomal SMase i.e., aSMase, and secretory SMase (sSMase) via alternative trafficking of the same protein precusor. ${ }^{9,10}$ ) The vascular endothelium and macrophages secrete sSMase, which is the only enzyme responsible for sphingolytic activity in plasma. ${ }^{11)}$

Elevated ceramide levels were recently shown to correlate with atherogenetic processes such as low-density lipoprotein (LDL) aggregation, ${ }^{12)}$ and form cell migration. ${ }^{13)}$ In relation to atherogenesis, we previously reported that the ceramide level in human plasma was positively correlated with both total cholesterol and oxidized apolipoprotein B-100 (oxLDL)

The authors declare no conflict of interest levels. ${ }^{14)}$ Deevska et al. ${ }^{15)}$ reported that LDL-SM content and sSMase activity in LDL receptor knockout mice, which were fed an atherogenic diet, were increased. Excessive cholesterol intake increased plasma ceramides in apolipoprotein E knockout mice $\left(\mathrm{apoE}^{-/-}\right)$, a typical animal model for atherosclerosis. ${ }^{16)}$ In addition, we previously reported that the increase in plasma ceramide level was caused by increased activity of sSMase in the streptozotocin-induced diabetic rats, ${ }^{17)}$ thus suggesting that the elevation of plasma ceramide was an important factor in atherogenesis. sSMase activity also increased in response to stimulation of macrophages obtained from patients with chronic heart failure ${ }^{18)}$ and type 2 diabetes. ${ }^{19)}$ These studies indicated that oxidative stress resulted in ceramide accumulation by increasing sSMase activity.

To investigate the effect of aging on ceramide metabolism, we compared changes in tissue ceramides and related enzymes in apoE $^{-/-}$with wild-type mice (WT), particularly focusing on SMase activity, which increased because of oxidative stress. ${ }^{17,20,21)}$

\section{MATERIALS AND METHODS}

Materials All the solvents were purchased from Wako Pure Chemical Industries, Ltd. (Osaka, Japan). All other reagents were obtained from Nacalai Tesque Inc. (Kyoto, Japan). Authentic ceramides were purchased from Avanti Polar Lipids Inc. (Alabaster, AL, U.S.A.). Nitrobenzofurazan (NBD) $\mathrm{C}_{6}-\mathrm{SM}$ was purchased from Molecular Probes Inc. (Eugene, OR, U.S.A.).

Animals This study was approved by the Animal Care Committee of Nara Women's University. Female WT (SLC: $\mathrm{C} 57 \mathrm{BL} / 6 \mathrm{~J}$; 4 or 13 weeks of age) were obtained from Japan SLC Co. (Hamamatsu, Shizuoka, Japan). Female apoE ${ }^{-/-}$were obtained from the Jackson Laboratory. The animals were housed in a room maintained at $24 \pm 2{ }^{\circ} \mathrm{C}$, with a $12 \mathrm{~h} / 12 \mathrm{~h}$ 
light/dark cycle. Animals were fed commercial laboratory chow (CE-2, Oriental Yeast Co., Osaka, Japan) and water ad libitum. Mice were sacrificed at the age of 7, 15, and 65 weeks (w) of age.

Analytical Methods Mice were anesthetized with Nembutal, and blood samples were collected by left ventricular puncture using a syringe containing sodium heparin as an anticoagulant. After perfusion with saline, the liver and aorta were dissected out. Plasma was separated from whole blood sample by centrifugation.

SMase Activity Assay SMase activities were measured using $\mathrm{NBD} \mathrm{C}_{6}-\mathrm{SM}$ as a substrate, and the assay was principally performed based on previous studies. ${ }^{17,22)}$ For sSMase analysis, a $800 \mu \mathrm{L}$ assay mixture consisted of $15 \mu \mathrm{L}$ of plasma and $785 \mu \mathrm{L}$ of an assay buffer $\left(0.1 \mathrm{~mm} \mathrm{ZnSO}_{4}, 1 \mathrm{nmol} \mathrm{NBD}\right.$ $\mathrm{C}_{6}$-SM, 0.1\% NP-40/62, $0.1 \mathrm{M}$ sodium acetate buffer at $\mathrm{pH} 5.0$ ) was incubated for $2 \mathrm{~h}$ at $37^{\circ} \mathrm{C}$. The reaction was stopped by adding $1 \mathrm{~mL}$ of methanol. For aortic aSMase, which depended on zinc ion, the aorta was dissected and cleaned of visible fat debris. The tissue was homogenized on ice in $400 \mu \mathrm{L}$ of phosphate buffered saline (10 mM, pH 7.4). Protein concentrations were determined according to the method of Lowry et $a{ }^{23)}$ Aortic aSMase activity was determined by suspending the homogenate $(1-2 \mathrm{mg}$ protein $/ \mathrm{mL})$ in $800 \mu \mathrm{L}$ assay mixture comprising of $0.1 \mathrm{~mm} \mathrm{ZnSO}_{4}, 1 \mathrm{nmol} \mathrm{NBD} \mathrm{C}_{6}-\mathrm{SM}, 0.1 \%$ $\mathrm{NP}-40 / 62$, and $0.1 \mathrm{M}$ sodium acetate ( $\mathrm{pH}$ 5.0). The reaction was continued for $2 \mathrm{~h}$ at $37^{\circ} \mathrm{C}$ and stopped by the addition of $2 \mathrm{~mL}$ methanol. $\mathrm{NBD} \mathrm{C}_{6}-\mathrm{SM}$ and generated $\mathrm{NBD} \mathrm{C}_{6}$-Ceramide were subsequently extracted according to the method of Bligh and Dyer. ${ }^{24)}$ The extract was dissolved in $0.5 \mathrm{~mL}$ methanol and analyzed using HPLC as described below. The samples $(20 \mu \mathrm{L})$ were directly analyzed by HPLC with a Nova Pak $4 \mu \mathrm{m}$ C18 column $(3.9 \times 150 \mathrm{~mm}$, Waters Corporation, Milford, MA, U.S.A.). Elution was performed at a flow rate of $1 \mathrm{~mL} /$ min with a mixture of water, acetonitrile, and phosphoric acid at a volume ratio of $35: 65: 0.2$. NBD fluorescence was determined using a fluorescence detector (Shimadzu, RF-10AXL, excitation at $466 \mathrm{~nm}$ and emission at $536 \mathrm{~nm}$ ).

Data were expressed as mean \pm S.E.M., and analyzed by multiple comparison tests using Statcel software (OMS Publishing Inc., Tokyo, Japan). Using the Tukey-Kramer Procedure, the differences between group means were significant at $p<0.05$.

Ceramide Measurement Lipids were extracted according to the method of Folch et al. ${ }^{25)}$ Lipids were dissolved in chloroform and subjected to chromatography on Silica gel 60 thin-layer chromatography (TLC) plates (Merck, Darmstradt, Germany). Separation was performed using silica gel 60 TLC plates (Merck, Germany) as previous studies. ${ }^{6,26)}$ In brief, the first elution was made with a mixture of $n$-butanol-acetic acid-water $(30: 10: 10, \mathrm{v} / \mathrm{v} / \mathrm{v})$ to the one third of the plate and the second elution was made to the top of the plate with a mixture of diethyl ether- $n$-hexane-acetic acid $(90: 10: 1$, $\mathrm{v} / \mathrm{v} / \mathrm{v})$. The ceramide spot was visualized under the UV by staining with primulin spray. The ceramide spot was scratched from the TLC plates and collected into a glass tube. Extraction was made with $2 \mathrm{~mL}$ of a mixture of $\mathrm{H}_{2} \mathrm{O}-\mathrm{CH}_{3} \mathrm{OH}-$ $\mathrm{CHCl}_{3}(20: 30: 50, \mathrm{v} / \mathrm{v} / \mathrm{v})$ under shaking for $30 \mathrm{~min}$. After centrifugation, the lower layer was collected. To the upper phase was added $1.5 \mathrm{~mL}$ of $\mathrm{CHCl}_{3}$, and extraction was made an additional two times. The collected $\mathrm{CHCl}_{3}$ solution was evaporated and resuspended in a mixture of $10 \mathrm{~mL}$ (liver) or $2 \mathrm{~mL}$ (aorta and plasma) of $\mathrm{CHCl}_{3}-\mathrm{CH}_{3} \mathrm{OH}(1: 9, \mathrm{v} / \mathrm{v})$. Standards and tissue ceramide extracts were stored at $-20^{\circ} \mathrm{C}$. The quantities of major ceramide species were measured by LC-MS/MS using a triple-quadrupole mass spectrometer [the ACQUITY TQD mass spectrometer (Waters Corporation, Milford, MA, U.S.A.)] equipped with the ACQUITY ultra performance liquid chromatography (UPLC) system (Waters Corporation, Milford, MA, U.S.A.). The ceramide species were separated using a column, [ACQUITY UPLC BEH, $1.7 \mu \mathrm{m}, 2.1 \times 50 \mathrm{~mm}$, C18 (Waters Corporation, Milford, MA, U.S.A.)] at $50^{\circ} \mathrm{C}$. UPLC gradient elution was applied beginning with $15 \%$ of mobile phase A (water containing $0.2 \%$ formic acid and $5 \mathrm{~mm}$ ammonium acetate) and $85 \%$ of mobile phase B (methanol containing $0.2 \%$ formic acid and $5 \mathrm{~mm}$ ammonium acetate) at a flow rate of $0.4 \mathrm{~mL} / \mathrm{min}$. The initial solvent condition was maintained for $3 \mathrm{~min}$, and the percentage of the B solution was gradually increased with a linear gradient to $99 \%$ for $6 \mathrm{~min}$. The column was equilibrated for $4 \mathrm{~min}$ with $85 \%$ mobile phase $\mathrm{B}$ prior to next injection. The total run time per injection was $13 \mathrm{~min}$. The mass spectrometry settings were as follows: electrospray ionization (ESI) positive ion mode, capillary voltage, $3.0 \mathrm{kV}$; cone voltage, $20 \mathrm{~V}$; source temperature, $120^{\circ} \mathrm{C}$; and desolvation temperature, $350^{\circ} \mathrm{C}$. The flow rates of nitrogen gas in the cone and desolvation gas were 50 and $600 \mathrm{~L} / \mathrm{h}$, respectively. Argon gas was used for collision-induced dissociation and maintenance of collision cell pressure at $10^{-4} \mathrm{mbar}$. Results were analyzed using multiple reaction monitoring (MRM). Mass spectra $(\mathrm{m} / \mathrm{z})$ for an internal standard (IS) and six major ceramides were set up at $426.4 \rightarrow 264.2$ for C8:0 ceramide (IS), and $538.4 \longrightarrow 264.2,566.5 \rightarrow 264.2,622.5 \rightarrow 264.3$, $650.6 \rightarrow 264.3,648.6 \rightarrow 264.3,646.6 \rightarrow 264.3$ for $\mathrm{C} 16: 0, \mathrm{C} 18: 0$, C22:0, C24:0, C24:1, and C24:2 ceramides, respectively. Data acquisition was carried out by MassLynx software (version 4.1, Waters Corporation). Ceramide species were quantified using standard curves and ratios of the integrated peak areas of each ceramide species and C8:0 ceramide, which was used as an internal standard for quantification of the other ceramide species. Total ceramide content was calculated by addition of the amount of C16:0, C18:0, C22:0, C24:0, C24:1, and C24:2 ceramides. Data were expressed as an mean \pm S.E.M.

\section{RESULTS}

Change in SMase Activity Plasma sSMase activity was significantly elevated at $65 \mathrm{w}$ of age in both $a \mathrm{apo}^{-/-}$and WT compared with level observed at $7 \mathrm{w}$ of age (Table 1). At $7 \mathrm{w}$

Table 1. Changes in sSMase Activity in Plasma (pmol $/ \mathrm{mL} / \mathrm{min}$ ) and Aortic aSMase Activity (pmol/mg protein/min) of Wild-Type and ApoE ${ }^{-/-}$Mice

\begin{tabular}{|c|c|c|c|c|c|c|}
\hline & $7 \mathrm{w}$ WT & $15 \mathrm{w}$ WT & $65 \mathrm{w}$ WT & $7 \mathrm{w}$ apoE $\mathrm{E}^{-/-}$ & $15 \mathrm{w}$ apo: $\mathrm{E}^{-/-}$ & $65 \mathrm{w}$ apo: $\mathrm{E}^{-/-}$ \\
\hline sSMase & $1599.6 \pm 171.6^{\mathrm{ab}}$ & $1666.7 \pm 83.6^{\mathrm{ab}}$ & $2688.7 \pm 175.1^{\mathrm{c}}$ & $657.3 \pm 86.9^{\mathrm{d}}$ & $1187.2 \pm 121.7^{\mathrm{ad}}$ & $1990.2 \pm 207.1^{b}$ \\
\hline Aortic aSMase & $79.2 \pm 9.4^{\mathrm{a}}$ & $130.8 \pm 12.5^{b c}$ & $271.5 \pm 14.3^{\mathrm{d}}$ & $113.8 \pm 13.5^{\mathrm{ab}}$ & $167.1 \pm 8.3^{\mathrm{c}}$ & $66.4 \pm 5.0^{\mathrm{a}}$ \\
\hline
\end{tabular}

Values are presented as mean \pm S.E.M. for 4 or 5 animals in each group. Different superscript letters indicate significant differences at $p<0.05$ (Tukey-Kramer post hoc test). 
of age, plasma sSMase activity was lower in $\mathrm{apoE}^{-/-}$than that in WT.

Aortic aSMase activity in WT was significantly elevated at $15 \mathrm{w}$ of age compared with the level observed at $7 \mathrm{w}$ of age, the level increased further at $65 \mathrm{w}$ of age (Table 1). In contrast, aortic aSMase activity in apoE $\mathrm{E}^{-/-}$was unchanged at $15 \mathrm{w}$ of age compared with that at $7 \mathrm{w}$ of age and declined significantly at $65 \mathrm{w}$ of age. Liver aSMase and neutral SMase activities were unchanged during aging in both $\mathrm{apoE}^{-/-}$and WT (data not shown).

Changes in Tissue Ceramide Levels The total aortic ceramide level in WT at $65 \mathrm{w}$ of age increased significantly compared with that observed at $7 \mathrm{w}$ of age (2.6-fold increase) (Table 2A). In the apoE $\mathrm{E}^{-/}$aorta, the total ceramide level was increased at $15 \mathrm{w}$ and $65 \mathrm{w}$ of age compared with the level observed at $7 \mathrm{w}$ of age $(2.0,1.9$-fold, respectively). The total aortic ceramide concentration of apoE $\mathrm{E}^{-/-}$was similar to that of WT at $7 \mathrm{w}$ of age (Table 2A); however, it was significantly higher than that of WT $(2.7$-fold $)$ at $15 \mathrm{w}$ of age. Table $2 \mathrm{~A}$ demonstrates the six major ceramide levels. In the WT aorta, C24:0, C24:1, and C24:2 ceramide levels at $65 \mathrm{w}$ of age were significantly higher than those at $7 \mathrm{w}$ of age $(2.6,2.9,6.0$-fold, respectively). In contrast, $\mathrm{C} 18: 0, \mathrm{C} 22: 0$, and $\mathrm{C} 24: 0$ ceramide levels in apoE $\mathrm{E}^{-/-}$aorta increased at $15 \mathrm{w}$ of age compared with those observed at $7 \mathrm{w}$ of age (2.7, 2.4, 2.2-fold, respectively). The C16:0, C24:1, and C24:2 ceramide levels in apoE $\mathrm{E}^{-/}$aorta at $65 \mathrm{w}$ of age increased compared with those at $7 \mathrm{w}$ of age (2.5, 2.3, 2.6-fold, respectively) (Table 2A).

Although the levels of almost all ceramide species changed in a similar manner to the total level, some ceramides showed a different behavior (Table 2A). The levels of C16:0, C18:0, $\mathrm{C} 22: 0$, and $\mathrm{C} 24: 0$ ceramides in the apo $\mathrm{E}^{-/-}$aorta were significantly higher than those of WT $(2.4,4.1,3.5,3.5$-fold, respectively) at $15 \mathrm{w}$ of age.

The total plasma ceramide level in apoE $\mathrm{E}^{-/-}$was significantly higher (4.4-5.9-fold) than that observed in WT at all ages

Table 2A. Levels of Ceramides in the Aorta of Wild-Type and ApoE ${ }^{-/-}$Mice

(A) Aorta ceramide levels (nmol/mg protein)

\begin{tabular}{|c|c|c|c|c|c|c|}
\hline Aorta & $7 \mathrm{w}$ WT & $15 \mathrm{w}$ WT & $65 \mathrm{w}$ WT & $7 \mathrm{w}$ apoE $\mathrm{E}^{-/-}$ & $15 \mathrm{w}$ apoE $\mathrm{E}^{-/-}$ & $65 \mathrm{w}$ apoE $\mathrm{E}^{-/-}$ \\
\hline C16:0 & $1.08 \pm 0.18^{\mathrm{a}}$ & $1.53 \pm 0.15^{\mathrm{a}}$ & $2.48 \pm 0.32^{\mathrm{ac}}$ & $2.03 \pm 0.46^{\mathrm{ac}}$ & $3.70 \pm 0.52^{b c}$ & $4.98 \pm 0.53^{b}$ \\
\hline C18:0 & $0.38 \pm 0.04^{\mathrm{a}}$ & $0.38 \pm 0.03^{\mathrm{a}}$ & $0.74 \pm 0.07^{\mathrm{a}}$ & $0.58 \pm 0.14^{\mathrm{a}}$ & $1.53 \pm 0.14^{\mathrm{b}}$ & $0.47 \pm 0.04^{\mathrm{a}}$ \\
\hline $\mathrm{C} 22: 0$ & $0.45 \pm 0.06^{\mathrm{ab}}$ & $0.44 \pm 0.05^{\mathrm{b}}$ & $0.95 \pm 0.13^{\mathrm{a}}$ & $0.66 \pm 0.14^{\mathrm{ab}}$ & $1.56 \pm 0.18^{\mathrm{bc}}$ & $0.94 \pm 0.08$ \\
\hline $\mathrm{C} 24: 0$ & $1.36 \pm 0.21^{\mathrm{ac}}$ & $1.33 \pm 0.10^{\mathrm{a}}$ & $3.52 \pm 0.46^{\mathrm{bd}}$ & $2.10 \pm 0.39^{\mathrm{ad}}$ & $4.69 \pm 0.55^{b}$ & $3.03 \pm 0.29^{\mathrm{cd}}$ \\
\hline $\mathrm{C} 24: 1$ & $0.58 \pm 0.12^{\mathrm{a}}$ & $1.03 \pm 0.12^{\mathrm{ab}}$ & $1.70 \pm 0.15^{\mathrm{b}}$ & $1.22 \pm 0.24^{\mathrm{ab}}$ & $1.79 \pm 0.25^{\mathrm{b}}$ & $2.82 \pm 0.31^{\mathrm{c}}$ \\
\hline $\mathrm{C} 24: 2$ & $0.17 \pm 0.03^{\mathrm{a}}$ & $0.39 \pm 0.06^{\mathrm{a}}$ & $1.02 \pm 0.13^{b}$ & $0.45 \pm 0.08^{\mathrm{a}}$ & $0.50 \pm 0.10^{\mathrm{a}}$ & $1.15 \pm 0.13^{\mathrm{b}}$ \\
\hline Total & $4.02 \pm 0.58^{\mathrm{a}}$ & $5.09 \pm 0.48^{\mathrm{a}}$ & $10.40 \pm 1.17^{\mathrm{bc}}$ & $7.03 \pm 1.42^{\mathrm{ab}}$ & $13.77 \pm 1.73^{\mathrm{cd}}$ & $13.39 \pm 1.23^{\mathrm{cd}}$ \\
\hline
\end{tabular}

Values are presented as mean \pm S.E.M. for 4 or 5 animals in each group. Total values are sum of six ceramide species. Different superscript letters indicate significant differences at $p<0.05$ (Tukey-Kramer post hoc test).

Table 2B. Levels of Ceramides in the Plasma of Wild-Type and ApoE ${ }^{-/-}$Mice

(B) Plasma ceramide levels $(\mathrm{nmol} / \mathrm{mL})$

\begin{tabular}{|c|c|c|c|c|c|c|}
\hline Plasma & $7 \mathrm{w} W \mathrm{~T}$ & $15 \mathrm{w}$ WT & $65 \mathrm{w}$ WT & $7 \mathrm{w}$ apoE $\mathrm{E}^{-/-}$ & $15 \mathrm{w}$ apoE $\mathrm{E}^{-/-}$ & $65 \mathrm{w}$ apoE $\mathrm{E}^{-/-}$ \\
\hline $\mathrm{C} 16: 0$ & $0.53 \pm 0.04^{\mathrm{a}}$ & $0.50 \pm 0.09^{a}$ & $0.47 \pm 0.05^{\mathrm{a}}$ & $5.63 \pm 0.42^{b}$ & $4.33 \pm 0.26^{\mathrm{c}}$ & $3.34 \pm 0.39^{\mathrm{c}}$ \\
\hline C18:0 & $0.14 \pm 0.03^{\mathrm{a}}$ & $0.20 \pm 0.03^{\mathrm{a}}$ & $0.16 \pm 0.02^{\mathrm{a}}$ & $0.82 \pm 0.10^{\mathrm{b}}$ & $0.85 \pm 0.05^{\mathrm{b}}$ & $0.47 \pm 0.07^{\mathrm{c}}$ \\
\hline $\mathrm{C} 22: 0$ & $1.06 \pm 0.12^{\mathrm{a}}$ & $0.98 \pm 0.15^{\mathrm{a}}$ & $0.79 \pm 0.06^{\mathrm{a}}$ & $8.50 \pm 1.12^{b}$ & $6.61 \pm 0.44^{\mathrm{b}}$ & $3.77 \pm 0.26^{\mathrm{c}}$ \\
\hline $\mathrm{C} 24: 0$ & $4.86 \pm 0.48^{\mathrm{a}}$ & $3.89 \pm 0.68^{a}$ & $2.96 \pm 0.38^{\mathrm{a}}$ & $25.76 \pm 3.44^{\mathrm{b}}$ & $16.81 \pm 0.82^{\mathrm{c}}$ & $12.08 \pm 0.64^{\mathrm{c}}$ \\
\hline $\mathrm{C} 24: 1$ & $2.82 \pm 0.46^{\mathrm{a}}$ & $3.20 \pm 0.55^{\mathrm{a}}$ & $2.33 \pm 0.24^{\mathrm{a}}$ & $14.84 \pm 1.90^{\mathrm{b}}$ & $12.93 \pm 0.58^{\mathrm{bc}}$ & $9.43 \pm 0.59^{c}$ \\
\hline $\mathrm{C} 24: 2$ & $0.20 \pm 0.05^{\mathrm{a}}$ & $0.22 \pm 0.04^{\mathrm{a}}$ & $0.21 \pm 0.02^{\mathrm{a}}$ & $1.05 \pm 0.05^{\mathrm{a}}$ & $1.01 \pm 0.07^{\mathrm{ab}}$ & $1.37 \pm 0.44^{\mathrm{b}}$ \\
\hline Total & $9.62 \pm 1.14^{\mathrm{a}}$ & $8.99 \pm 1.48^{\mathrm{a}}$ & $6.92 \pm 0.72^{\mathrm{a}}$ & $56.60 \pm 6.54^{\mathrm{b}}$ & $42.53 \pm 1.81^{\mathrm{c}}$ & $30.46 \pm 1.74^{c}$ \\
\hline
\end{tabular}

Values are presented as mean \pm S.E.M. for 4 or 5 animals in each group. Total values are sum of six ceramide species. Different superscript letters indicate significant differences at $p<0.05$ (Tukey-Kramer post hoc test).

Table 2C. Levels of Ceramides in the Liver of Wild-Type and ApoE ${ }^{-/-}$Mice

\begin{tabular}{|c|c|c|c|c|c|c|}
\hline \multicolumn{7}{|c|}{ (C) Liver ceramide levels ( $\mathrm{nmol} / \mathrm{g}$ tissue) } \\
\hline Liver & $7 \mathrm{w}$ WT & $15 \mathrm{w}$ WT & $65 \mathrm{w}$ WT & $7 \mathrm{w}$ apoE $\mathrm{E}^{-/-}$ & $15 \mathrm{w}$ apoE $\mathrm{E}^{-/-}$ & $65 \mathrm{w}$ apoE $\mathrm{E}^{-/-}$ \\
\hline C16:0 & $47.03 \pm 4.12^{\mathrm{a}}$ & $72.29 \pm 5.66^{\mathrm{b}}$ & $60.20 \pm 5.22^{\mathrm{ab}}$ & $52.47 \pm 4.87^{\mathrm{ab}}$ & $56.07 \pm 2.02^{\mathrm{ab}}$ & $55.09 \pm 3.71^{\mathrm{ab}}$ \\
\hline C18:0 & $8.03 \pm 0.85^{\mathrm{a}}$ & $16.48 \pm 2.15^{\mathrm{b}}$ & $13.10 \pm 0.29^{\mathrm{ab}}$ & $10.19 \pm 1.54^{\mathrm{a}}$ & $12.02 \pm 1.35^{\mathrm{ab}}$ & $8.07 \pm 0.98^{\mathrm{a}}$ \\
\hline $\mathrm{C} 22: 0$ & $44.14 \pm 1.96^{\mathrm{a}}$ & $65.93 \pm 3.69^{b}$ & $67.06 \pm 3.28^{\mathrm{b}}$ & $66.16 \pm 7.25^{\mathrm{b}}$ & $65.48 \pm 4.23^{\mathrm{b}}$ & $38.75 \pm 2.36^{\mathrm{a}}$ \\
\hline $\mathrm{C} 24: 0$ & $128.87 \pm 5.43^{\mathrm{ab}}$ & $169.37 \pm 10.78^{a}$ & $156.39 \pm 16.47^{\mathrm{ab}}$ & $178.40 \pm 19.69^{a}$ & $153.40 \pm 6.30^{\mathrm{ab}}$ & $105.94 \pm 4.78^{b}$ \\
\hline $\mathrm{C} 24: 1$ & $201.38 \pm 11.52^{\mathrm{a}}$ & $283.16 \pm 13.98^{b}$ & $239.44 \pm 12.91^{\mathrm{ab}}$ & $200.30 \pm 8.90^{\mathrm{a}}$ & $247.01 \pm 11.85^{a b}$ & $208.74 \pm 10.94^{\mathrm{a}}$ \\
\hline $\mathrm{C} 24: 2$ & $16.67 \pm 0.97$ & $22.33 \pm 1.70$ & $20.40 \pm 3.24$ & $21.30 \pm 1.83$ & $24.23 \pm 1.11$ & $24.11 \pm 3.87$ \\
\hline Total & $446.12 \pm 22.95^{\mathrm{ac}}$ & $629.55 \pm 29.14^{\mathrm{b}}$ & $556.58 \pm 26.09^{\mathrm{ab}}$ & $528.82 \pm 35.68^{\mathrm{abc}}$ & $558.22 \pm 15.30^{\mathrm{ab}}$ & $440.69 \pm 19.06^{\mathrm{c}}$ \\
\hline
\end{tabular}

Values are presented as mean \pm S.E.M. for 4 or 5 animals in each group. Total values are sum of six ceramide species. Different superscript letters indicate significant differences at $p<0.05$ (Tukey-Kramer post hoc test). 
(Table 2B). Almost all plasma ceramide species in apoE $\mathrm{E}^{-/}$decreased with age with the exception of C24:2 ceramide (Table 2B).

The total ceramide level in WT liver increased at $15 \mathrm{w}$ at age (Table 2C) and the levels of C16:0, C18:0, C22:0, and C24:1 ceramides were highest at $15 \mathrm{w}$ of age (Table $2 \mathrm{C}$ ). In apoE $^{-/-}$liver, $\mathrm{C} 22: 0$ ceramide level at $7 \mathrm{w}$ of age was significantly higher than that observed in WT, whereas C22:0 ceramide level and total ceramide level at $65 \mathrm{w}$ of age were significantly lower in apo $\mathrm{E}^{-/-}$than those in WT.

\section{DISCUSSION}

The total plasma ceramide level in $\mathrm{apoE}^{-/-}$was comparable to that reported for human atherosclerotic subjects, ${ }^{14)}$ and was significantly higher than the level observed in WT at all ages, indicating that the aorta of $\mathrm{apoE}^{-/-}$was exposed to a higher plasma ceramide level throughout aging. The difference in the plasma ceramide levels between $\mathrm{WT}$ and $\mathrm{apoE}^{-/-}$may be attributed to the LDL level in plasma because LDL is the major ceramide carrier. $^{27,28)}$ The plasma ceramide level correlated with the LDL cholesterol and oxLDL levels in human samples. ${ }^{14)}$ The plasma ceramide level in apoE ${ }^{-/-}$decreased during aging. As a similar phenomemon was reported for oxLDL by Itabe and colleagues ${ }^{29)}$ : the level of oxLDL increased at $20 \mathrm{w}$ of age and decreased toward the basal level at $40 \mathrm{w}$ of age in apoE $\mathrm{E}^{-/-}$. These authors suggested that oxLDL appeared before the development of atherosclerotic lesions. Moreover, Schissel et $a l^{30)}$ indicated that ceramides, generated by sSMase from the lesional LDL, but not from the plasma LDL, participated in LDL aggregation. Combining these reports with the results from this study, in which aortic ceramide levels increased at $15 \mathrm{w}$ of age in $\mathrm{apoE}^{-/}$, it is suggested that an elevation in ceramide level at the beginning of atherogenesis is involved in the pathogenesis of atherosclerosis.

Although the aortic ceramide level increased significantly in both WT and apoE $\mathrm{E}^{-/-}$, the distribution pattern of ceramide species in WT and apoE $\mathrm{E}^{-/-}$was different. At $15 \mathrm{w}$ of age, when atherogenesis was assumed to initiate in $a p o E^{-/-31,32)}$ the levels of $\mathrm{C} 16: 0, \mathrm{C} 18: 0, \mathrm{C} 22: 0$, and $\mathrm{C} 24: 0$ ceramides in the aorta increased significantly, whereas only C16:0 and C24:1 ceramide levels increased at $65 \mathrm{w}$ of age. The aortic levels of C18:0, C22:0, and C24:0 ceramides caused a similar change in aortic SMase activity. On the basis of these results, we suggest that the increase in C18-24 ceramide levels and the elevation of aortic aSMase activity may play a role in the initiation of atherogenesis. In addition, this is the first study showing elevation of aortic ceramide level during aging in $\operatorname{apoE}^{-/-}$as well as in WT.

In contrast to $\mathrm{C} 24$ ceramide, $\mathrm{C} 16: 0$ ceramide, a major ceramide in the aorta of $\mathrm{apoE}^{-/-}$that increased at 15 and $65 \mathrm{w}$ of age, seemed to have a different function. Ceramide chain length affects the physicochemical properties of lipid membranes; ${ }^{33)}$ thus, C16:0 ceramide easily mixes with cholesterol in contrast to $\mathrm{C} 24$ ceramide. $^{34)}$ Mesicek et $a l .{ }^{35)}$ reported that the overexpression of ceramide synthase (CerS) 5 lead to generation of $\mathrm{C} 16: 0$ ceramide and an increase in apoptosis, whereas overexpression of CerS2 yielded C24 ceramide and provoked pro-survival signals. Furthermore, in the liver of CerS2 null mice, elevated ROS levels are associated with an increase in $\mathrm{C} 16: 0$ ceramide and a decrease in mitochondria complex IV activity. ${ }^{36)}$ In this regard, cellular homeostasis appears to be maintained by a balance between C16:0 and C24:0 ceramides. Although the present study showed that C16:0 ceramide behaved in a manner similar to the very long, unsaturated $\mathrm{C} 24: 1$ ceramide, the relationship between atherogenesis and apoptosis caused by ceramides, particularly C16:0 and $\mathrm{C} 24$ ceramides, requires further examination.

Liver ceramide levels were unchanged with aging in either $\mathrm{apoE}^{-/-}$or WT. Similar results were obtained in diabetic rats. ${ }^{17)}$ These observations suggested that aging did not affect hepatic ceramide metabolism.

In conclusion, this study suggests that elevation of ceramide species such as C16:0 in the aorta as a result of sSMase activity in the plasma contributes to atherogenesis during aging.

Acknowledgment This work was supported by Grant-inAid from the Ministry of Education, Culture, Sports, Science and Technology of Japan.

\section{REFERENCES}

1) Hannun YA, Obeid LM. The ceramide-centric universe of lipidmediated cell regulation: stress encounters of the lipid kind. J. Biol. Chem., 277, 25847-25850 (2002).

2) Kolesnick R. Ceramide: a novel second messenger. Trends Cell Biol., 2, 232-236 (1992).

3) Farrell AM, Uchida Y, Nagiec MM, Harris IR, Dickson RC, Elias PM, Holleran WM. UVB irradiation up-regulates serine palmitoyltransferase in cultured human keratinocytes. J. Lipid Res., 39, 2031-2038 (1998).

4) Santana P, Peña LA, Haimovitz-Friedman A, Martin S, Green D, McLoughlin M, Cordon-Cardo C, Schuchman EH, Fuks Z, Kolesnick R. Acid sphingomyelinase-deficient human lymphoblasts and mice are defective in radiation-induced apoptosis. Cell, 86, 189-199 (1996).

5) Merrill AH Jr, Jones DD. An update of the enzymology and regulation of sphingomyelin metabolism. Biochim. Biophys. Acta, 1044, 1-12 (1990).

6) Yamada Y, Kajiwara K, Yano M, Kishida E, Masuzawa Y, Kojo S. Increase of ceramides and its inhibition by catalase during chemically induced apoptosis of HL-60 cells determined by electrospray ionization tandem mass spectrometry. Biochim. Biophys. Acta, 1532, 115-120 (2001).

7) Goñi FM, Alonso A. Sphingomyelinases: enzymology and membrane activity. FEBS Lett., 531, 38-46 (2002).

8) Schuchman EH. Acid sphingomyelinase, cell membranes and human disease: lessons from Niemann-Pick disease. FEBS Lett., 584, 1895-1900 (2010).

9) Schissel SL, Keesler GA, Schuchman EH, Williams KJ, Tabas I. The cellular trafficking and zinc dependence of secretory and lysosomal sphingomyelinase, two products of the acid sphingomyelinase gene. J. Biol. Chem., 273, 18250-18259 (1998).

10) Jenkins RW, Canals D, Idkowiak-Baldys J, Simbari F, Roddy P, Perry DM, Kitatani K, Luberto C, Hannun YA. Regulated secretion of acid sphingomyelinase: implications for selectivity of ceramide formation. J. Biol. Chem., 285, 35706-35718 (2010).

11) Tabas I. Secretory sphingomyelinase. Chem. Phys. Lipids, 102, 123-130 (1999).

12) Walters MJ, Wrenn SP. Effect of sphingomyelinase-mediated generation of ceramide on aggregation of low-density lipoprotein. Langmuir, 24, 9642-9647 (2008).

13) Morita SY, Kawabe M, Sakurai A, Okuhira K, Vertut-Doï A, Nakano M, Handa T. Ceramide in lipid particles enhances heparan sulfate proteoglycan and low density lipoprotein receptor-related 
protein-mediated uptake by macrophages. J. Biol. Chem., 279, 24355-24361 (2004).

14) Ichi I, Nakahara K, Miyashita Y, Hidaka A, Kutsukake S, Inoue K, Maruyama T, Miwa Y, Harada-Shiba M, Tsushima M, Kojo S, Kisei Cohort Study Grooup. Association of ceramides in human plasma with risk factors of atherosclerosis. Lipids, 41, 859-863 (2006).

15) Deevska GM, Sunkara M, Morris AJ, Nikolova-Karakashian MN. Characterization of secretory sphingomyelinase activity, lipoprotein sphingolipid content and LDL aggregation in $\mathrm{ldlr}^{-/-}$mice fed on a high-fat diet. Biosci. Rep., 32, 479-490 (2012).

16) Ichi I, Takashima Y, Adachi N, Nakahara K, Kamikawa C, HaradaShiba M, Kojo S. Effects of dietary cholesterol on tissue ceramides and oxidation products of apolipoprotein B-100 in ApoE-deficient mice. Lipids, 42, 893-900 (2007).

17) Kobayashi K, Ichi I, Nakagawa T, Kamikawa C, Kitamura Y, Koga E, Washino Y, Hoshinaga Y, Kojo S. Increase in plasma ceramide levels via secretory sphingomyelinase activity in streptozotocininduced diabetic rats. Med. Chem. Commun., 2, 536-541 (2011).

18) Doehner W, Bunck AC, Rauchhaus M, von Haehling S, Brunkhorst FM, Cicoira M, Tschope C, Ponikowski P, Claus RA, Anker SD. Secretory sphingomyelinase is upregulated in chronic heart failure: a second messenger system of immune activation relates to body composition, muscular functional capacity, and peripheral blood flow. Eur. Heart J., 28, 821-828 (2007).

19) Górska M, Barańczuk E, Dobrzyń A. Secretory $\mathrm{Zn}^{2+}$-dependent sphingomyelinase activity in the serum of patients with type 2 diabetes is elevated. Horm. Metab. Res., 35, 506-507 (2003).

20) Filosto S, Fry W, Knowlton AA, Goldkorn T. Neutral sphingomyelinase 2 (nSMase2) is a phosphoprotein regulated by calcineurin (PP2B). J. Biol. Chem., 285, 10213-10222 (2010).

21) Ichi I, Kamikawa C, Nakagawa T, Kobayashi K, Kataoka R, Nagata E, Kitamura Y, Nakazaki C, Matsura T, Kojo S. Neutral sphingomyelinase-induced ceramide accumulation by oxidative stress during carbon tetrachloride intoxication. Toxicology, 261, 33-40 (2009).

22) Lightle SA, Oakley JI, Nikolova-Karakashian MN. Activation of sphingolipid turnover and chronic generation of ceramide and sphingosine in liver during aging. Mech. Ageing Dev., 120, 111-125 (2000).

23) Lowry OH, Rosebrough NJ, Farr AL, Randall RJ. Protein measurement with the Folin phenol reagent. J. Biol. Chem., 193, 265-275 (1951).

24) Bligh EG, Dyer WJ. A rapid method of total lipid extraction and purification. Can. J. Biochem. Physiol., 37, 911-917 (1959).

25) Folch J, Ascoli I, Lees M, Meath JA, LeBaron N. Preparation of lipid extracts from brain tissue. J. Biol. Chem., 191, 833-841 (1951).

26) Yano M, Kishida E, Muneyuki Y, Masuzawa Y. Quantitative analysis of ceramide molecular species by high performance liquid chromatography. J. Lipid Res., 39, 2091-2098 (1998).

27) Wiesner P, Leidl K, Boettcher A, Schmitz G, Liebisch G. Lipid profiling of FPLC-separated lipoprotein fractions by electrospray ionization tandem mass spectrometry. J. Lipid Res., 50, 574-585 (2009).

28) Hammad SM, Pierce JS, Soodavar F, Smith KJ, Al Gadban MM, Rembiesa B, Klein RL, Hannun YA, Bielawski J, Bielawska A. Blood sphingolipidomics in healthy humans: impact of sample collection methodology. J. Lipid Res., 51, 3074-3087 (2010).

29) Kato R, Mori C, Kitazato K, Arata S, Obama T, Mori M, Takahashi $\mathrm{K}$, Aiuchi T, Takano T, Itabe H. Transient increase in plasma oxidized LDL during the progression of atherosclerosis in apolipoprotein E knockout mice. Arterioscler. Thromb. Vasc. Biol., 29, 33-39 (2009).

30) Schissel SL, Tweedie-Hardman J, Rapp JH, Graham G, Williams KJ, Tabas I. Rabbit aorta and human atherosclerotic lesions hydrolyze the sphingomyelin of retained low-density lipoprotein. Proposed role for arterial-wall sphingomyelinase in subendothelial retention and aggregation of atherogenic lipoproteins. J. Clin. Invest., 98, 1455-1464 (1996).

31) Plump AS, Smith JD, Hayek T, Aalto-Setälä K, Walsh A, Verstuyft JG, Rubin EM, Breslow JL. Severe hypercholesterolemia and atherosclerosis in apolipoprotein E-deficient mice created by homologous recombination in ES cells. Cell, 71, 343-353 (1992).

32) Zhang SH, Reddick RL, Piedrahita JA, Maeda N. Spontaneous hypercholesterolemia and arterial lesions in mice lacking apolipoprotein E. Science, 258, 468-471 (1992).

33) Grösch S, Schiffmann S, Geisslinger G. Chain length-specific properties of ceramides. Prog. Lipid Res., 51, 50-62 (2012).

34) ten Grotenhuis E, Demel RA, Ponec M, Boer DR, van Miltenburg JC, Bouwstra JA. Phase behavior of stratum corneum lipids in mixed Langmuir-Blodgett monolayers. Biophys. J., 71, 1389-1399 (1996).

35) Mesicek J, Lee H, Feldman T, Jiang X, Skobeleva A, Berdyshev EV, Haimovitz-Fridman A, Fuks Z, Kolesnick R. Ceramide synthases 2 , 5 , and 6 confer distinct roles in radiation-induced apoptosis in $\mathrm{HeLa}$ cells. Cell. Signal., 22, 1300-1307 (2010).

36) Zigdon H, Kogot-Levin A, Park JW, Goldschmidt R, Kelly S, Merrill AH Jr, Scherz A, Pewzner-Jung Y, Saada A, Futerman AH. Ablation of ceramide synthase 2 causes chronic oxidative stress due to disruption of the mitochondrial respiratory chain. J. Biol. Chem., 288, 4947-4956 (2013). 